\title{
Cytological Indices of Postpartum Normally Calved Dairy Cows
}

\author{
S. Alagar*, M. Selvaraju and R. Ezakial Napolean \\ Department of Veterinary Gynaecology and Obstetrics, Veterinary College and Research \\ institute, Namakkal - 2, Tamil Nadu, India \\ *Corresponding author
}

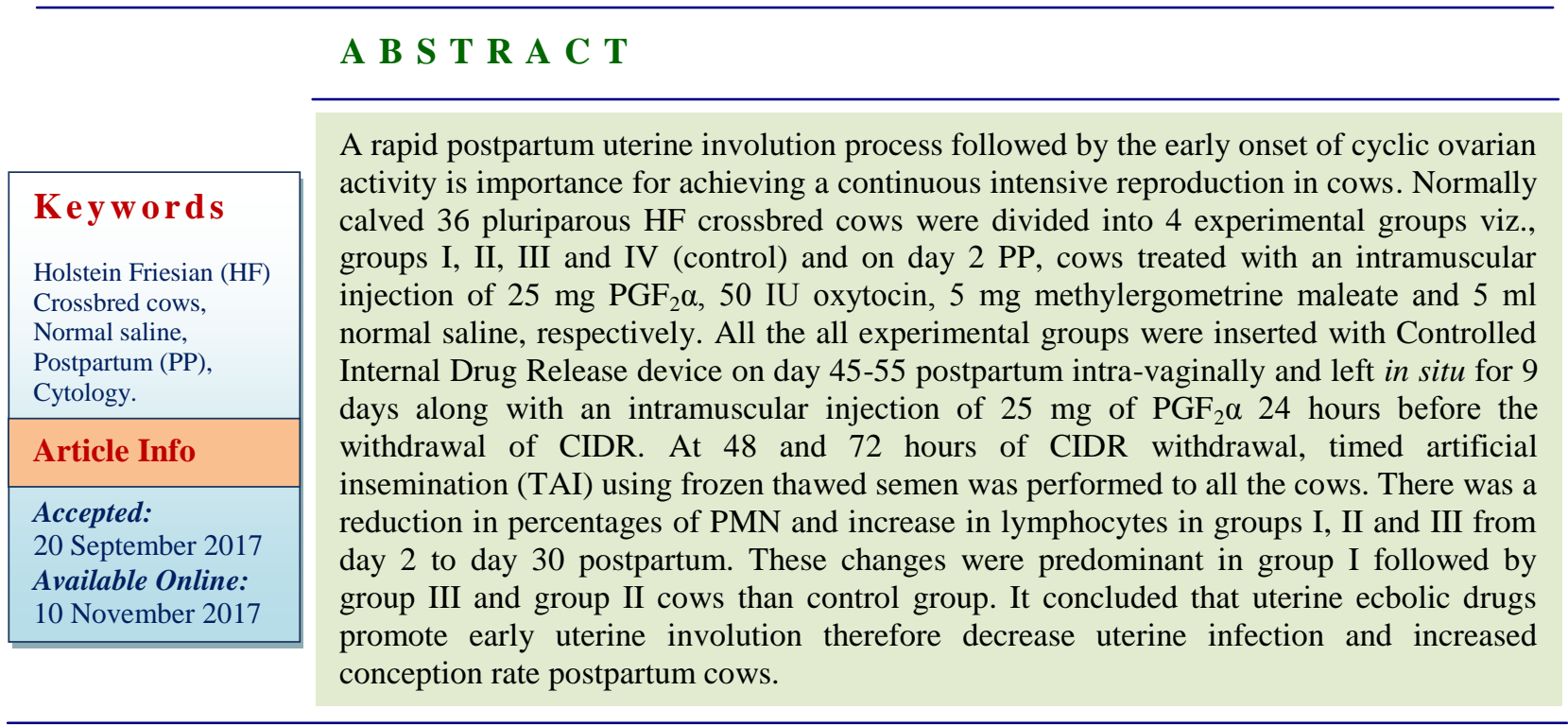

\section{Introduction}

Fertility after parturition of dairy cows is considered as the principal economic factor of milk producing farms. Alteration or extension of postpartum period with failure or delay in conception results in progressive economic loss to the poor farming community (Patel et $a l ., 2006)$.Therefore, the puerperal period is a critical phase in the reproductive cycle of dairy cows (Frazer, 2005).Puerperal uterine soundness is essential for the re-establishment of postpartum ovarian cyclicity and next pregnancy (Tiwari et al., 2004).

Four main events during puerperium in bovines are contraction of myometrium and expulsion of lochia, elimination of bacterial contamination in genital system, anatomical and histological restoration of uterus and return of ovarian cyclicity (Nakao et al., 1992andPeter et al., 2009). Involution of the genital tract after parturition aids the resolution of uterine infection and conversely may be delayed by uterine disease. Delay in the completion of uterine involution and resumption of ovarian activity decreases the reproductive efficiency in cows.

A complex relationship exists between factors influencing uterine health and disease in the postpartum cow (Nebel, 1999). Reproductive 
performance of dairy cows after the voluntary waiting period is highly related to the health status of the uterus after calving (Dijkhuizen and Stelwagen, 1985 and Ferguson and Galligan, 2000). Puerperal uterine diseases may prolong the anovulatory interval by up to 10 days (Zain et al., 1995). The rate of conception depends on the time required for involution of uterus and recurrence of oestrus.

\section{Cytology of uterus}

For cytological studies of uterus, different approaches viz. direct swab (Chapwanya et al., 2010), cytobrush (Barlund et al., 2008) and lavage techniques (Kasimanickam et al., 2005) were adopted for collecting uterine secretions. The cytological smears have been evaluated after staining with either Giemsa or Wright stains (Kasimanickam et al., 2005; Azawi, 2008). The proportion of polymorphonuclear leucocytes (PMN) in the total number of endometrial cells is indicative for subclinical endometritis (Dolatkhah et al., 2013). Reports on the use of endometrial cytology for the diagnosis of clinical endometritis, however, are limited to one recent study that described endometrial cytology as the most reliable method of diagnosing endometritis in cattle (Barlund et al., 2008). The accumulation of intrauterine fluid has been shown to be associated with bacterial growth and delayed uterine involution (Mateus et al., 2002).

Among the differential leucocytic count, PMN cells were found to be 12.33 (Singh et al., 2000) and $1.99 \pm 0.43$ per cent (Promod et al., 2002) in uterine flushings of cows affected with endometritis. While other cells such as lymphocyte and epithelial cell per cent in uterine flushings of follicular phase were recorded to be $14.09 \pm 3.01$ and $85.56 \pm$ 3.11 and in endometritis affected uteri of buffalos, they were $14.43 \pm 1.94$ and $83.58 \pm$ 1.99 per cent, respectively (Promod et al.,
2002). In this present study uterine flushing techniques with sterile normal saline solution used to harvest the endometrial cytology in repeat breeding cows, to evaluate the clearance or reduce the PMN cell population in the uterine lumen to increase the conception rate in repeat breeder cows.

\section{Materials and Methods}

Normally calved 36 healthy Holstein Friesian crossbred cows aged between $2^{\text {nd }}$ and $5^{\text {th }}$ lactations were selected immediately after parturition. Day of parturition was considered as day 0 of the experiment. All the selected cows were randomly and equally divided into 4 experimental groups viz., group I, II, III and IV (control). Therefore each group consisted of 9 cows. On day 2 postpartum, cows of group I,II,III and IV were treated with an intramuscular injection of $25 \mathrm{mg} \mathrm{PGF}_{2} \alpha$ (Dinoprost Tromethamine, 5ml, Lutalyse ${ }^{\circledR}$, Pfizer Animal Health India Ltd, India), 50 IU oxytocin $\left(10 \mathrm{ml}\right.$, Syntophar ${ }^{\circledR}$, Interphar Healthcare Pvt. Ltd., Chandigarh, India), 5 mg methylergometrine maleate $(5 \mathrm{ml}$, Utrasafe $^{\circledR}$, Vet Mankind, New Delhi, India) and $5 \mathrm{ml}$ normal saline (Parental drugs (India) limited, Indore, Madhya Pradesh, India), respectively.

\section{Cytological studies of lochia / uterine fluid}

In all the cows, cytological studies of uterus were carried out on day 2, 10, 20 and 30 postpartum. About $60 \mathrm{ml}$ of 0.9 per cent sodium chloride solution was infused into the uterus using $52 \mathrm{~cm}$ disposable plastic infusion sheath fitted with $60 \mathrm{ml}$ syringe containing the solution. Then the uterus was massaged gently and fluid was recovered by negative pressure aspiration into the syringe. The collected fluid was transferred to a $50 \mathrm{ml}$ modified polystyrene centrifuge tube without any preservatives. The collected samples were brought to the laboratory within 2 hours and 
centrifuged at $1000 \mathrm{rpm}$ for 5 minutes. The supernatant fluid was discarded and a small drop of sediment was streaked on to a clean, grease free glass slide and air dried. All the slides were fixed with methanol and stained with modified Giemsastain for 20 minutes (Singh et al., 2000) and the cells were counted and percentages of differential count were recorded (Schalm et al., 1975).

\section{Results and Discussion}

The mean $( \pm \mathrm{SE})$ percentages of polymorphonuclear leucocytes (PMN), lymphocytes (L) and monocytes (M) found in the uterus of experimental and control cows are presented in Table 1 (Figs. 1 and 2).

No eosinophil and basophil could be detected in uterine fluid in all the groups of this study.

The results indicated that there was a reduction in percentages of PMN and increase in lymphocytes in groups I, II and III from day 2 to day 30 postpartum. These changes were predominant in group I followed by group III and group II cows indicating the absence of bacterial infection in uterine ecbolics treated cows.

Table.1 Cytology of uterine fluid in cows treated with uterine ecbolics

\begin{tabular}{|c|c|c|c|c|c|c|}
\hline \multirow{2}{*}{$\begin{array}{l}\text { S. } \\
\text { No. }\end{array}$} & & & \multicolumn{4}{|c|}{ Differential leucocyte count } \\
\hline & & & $\begin{array}{c}\text { Day } 2 \\
\text { postpartum }\end{array}$ & $\begin{array}{c}\text { Day } 10 \\
\text { postpartum }\end{array}$ & $\begin{array}{c}\text { Day } 20 \\
\text { postpartum }\end{array}$ & $\begin{array}{c}\text { Day } 30 \\
\text { postpartum }\end{array}$ \\
\hline \multirow{3}{*}{1.} & \multirow{3}{*}{$\begin{array}{c}\text { Group } \\
\text { I }\end{array}$} & PMN & $92.56^{\mathrm{a}} \pm 0.80$ & $77.11^{\mathrm{b}} \pm 0.79$ & $72.33^{c} \pm 1.20$ & $73.44^{\mathrm{c}} \pm 0.88$ \\
\hline & & $\mathrm{L}$ & $5.33^{\mathrm{a}} \pm 0.24$ & $21.22^{\mathrm{b}} \pm 0.62$ & $26.33^{\mathrm{c}} \pm 0.78$ & $25.51^{\mathrm{c}} \pm 0.67$ \\
\hline & & $M$ & $2.11^{\mathrm{a}} \pm 0.26$ & $1.67^{\mathrm{b}} \pm 0.26$ & $1.34^{\mathrm{b}} \pm 0.35$ & $1.05^{\mathrm{b}} \pm 0.33$ \\
\hline \multirow{3}{*}{2.} & \multirow{3}{*}{$\begin{array}{c}\text { Group } \\
\text { II }\end{array}$} & $\mathrm{PMN}$ & $83.89^{\mathrm{a}} \pm 0.65$ & $77.89^{\mathrm{b}} \pm 0.72$ & $70.56^{\mathrm{c}} \pm 0.93$ & $75.56^{\mathrm{d}} \pm 0.84$ \\
\hline & & $\mathrm{L}$ & $15.11^{\mathrm{a}} \pm 0.85$ & $17.22^{\mathrm{b}} \pm 0.36$ & $26.44^{\mathrm{c}} \pm 2.21$ & $23.22^{\mathrm{d}} \pm 1.18$ \\
\hline & & $\mathrm{M}$ & $1.00^{\mathrm{a}} \pm 0.26$ & $4.89^{\mathrm{b}} \pm 0.22$ & $3.00^{\mathrm{c}} \pm 0.29$ & $1.22^{\mathrm{a}} \pm 0.31$ \\
\hline \multirow{3}{*}{3.} & \multirow{3}{*}{$\begin{array}{c}\text { Group } \\
\text { III }\end{array}$} & PMN & $92.47^{\mathrm{a}} \pm 1.34$ & $88.68^{\mathrm{b}} \pm 1.30$ & $72.33^{c} \pm 1.20$ & $73.72^{\mathrm{c}} \pm 0.98$ \\
\hline & & $\mathrm{L}$ & $6.38^{\mathrm{a}} \pm 0.36$ & $5.89^{\mathrm{a}} \pm 0.39$ & $26.33^{\mathrm{b}} \pm 0.78$ & $24.29^{c} \pm 0.19$ \\
\hline & & M & $1.15 \pm 0.24$ & $1.88 \pm 0.26$ & $1.34 \pm 0.24$ & $1.99 \pm 0.34$ \\
\hline \multirow{3}{*}{4.} & \multirow{3}{*}{$\begin{array}{c}\text { Group } \\
\text { IV }\end{array}$} & PMN & $86.44^{\mathrm{a}} \pm 0.38$ & $84.56^{\mathrm{a}} \pm 0.56$ & $91.67^{\mathrm{b}} \pm 0.50$ & $88.22^{\mathrm{C}} \pm 0.74$ \\
\hline & & $\mathrm{L}$ & $11.89^{\mathrm{a}} \pm 0.48$ & $14.33^{\mathrm{b}} \pm 0.47$ & $6.56^{\mathrm{c}} \pm 0.50$ & $10.22^{\mathrm{d}} \pm 0.43$ \\
\hline & & M & $1.67 \pm 0.17$ & $1.11 \pm 0.26$ & $1.77 \pm 0.18$ & $1.56 \pm 0.22$ \\
\hline
\end{tabular}

Means bearing different superscript between column $(a, b, c)$ within each row differed significantly $(p<0.05)$. PMN - polymorphonuclear leucocytes, L-Lymphocytes, M-Monocytes.

Group I- PGF 2 , Group II-Methylergometrine maleate, Group III- Oxytocin, Group IV-Control. 


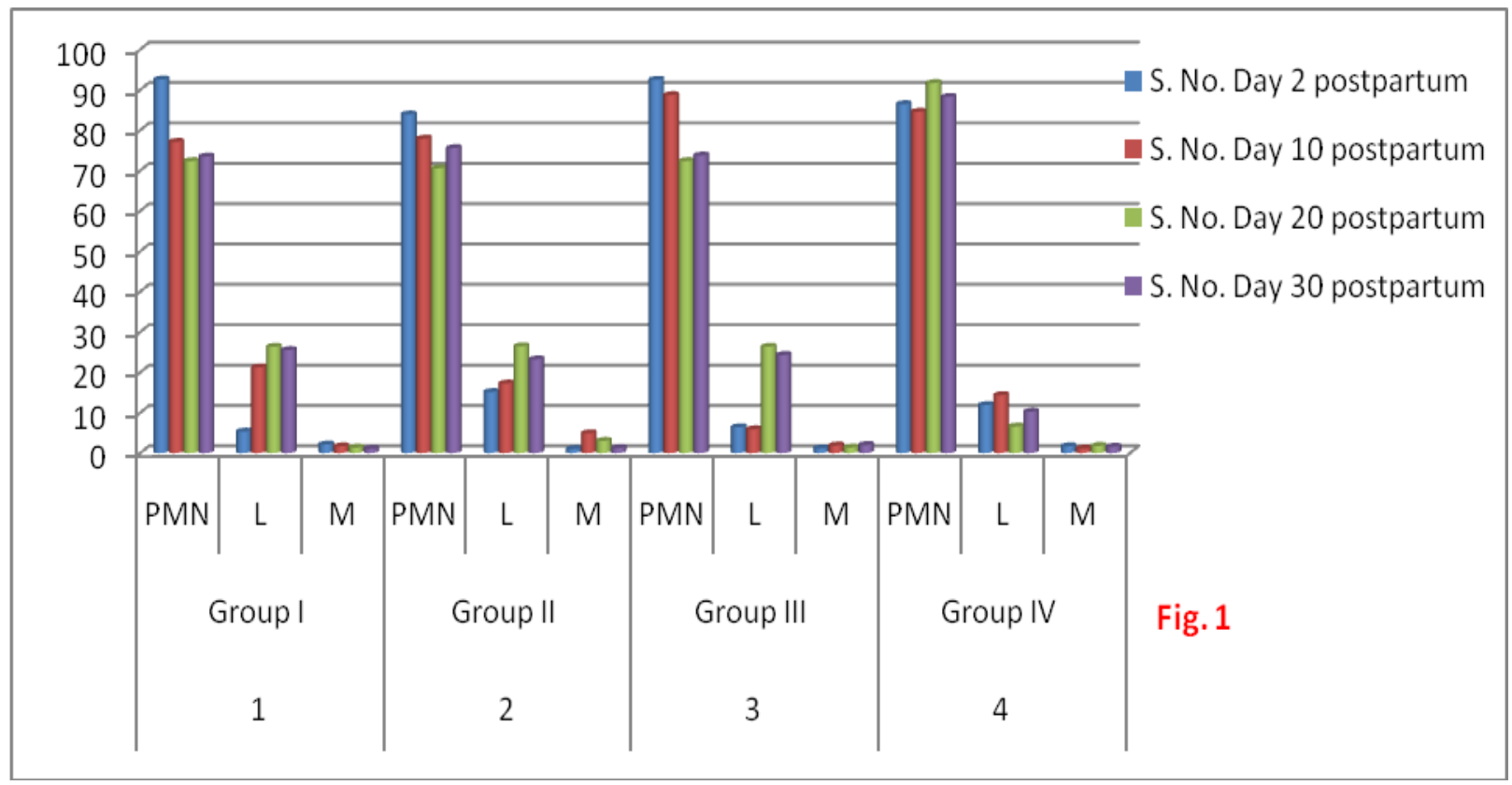

\section{Cytology of the postpartum uterus}

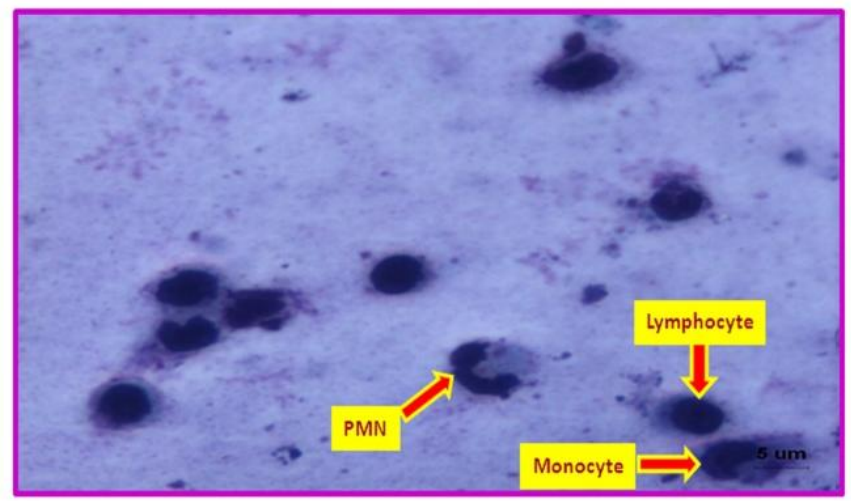

Giemsa staining Bar=5um

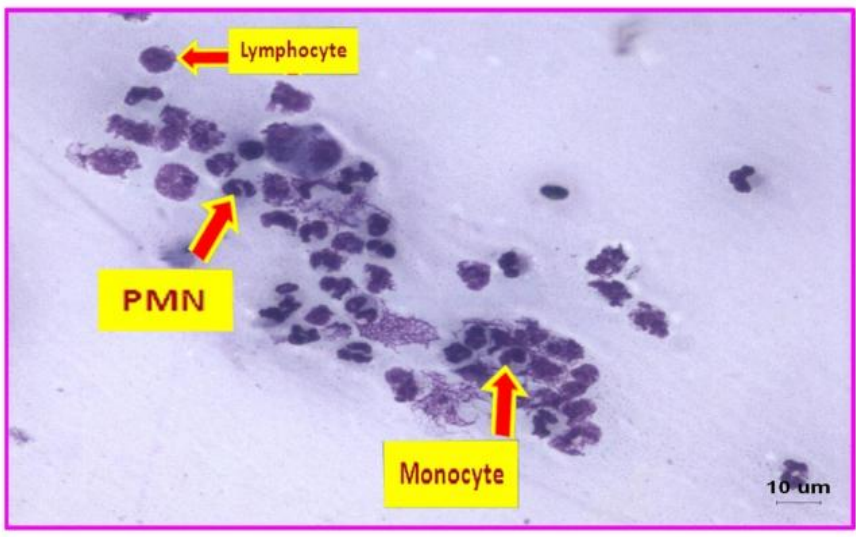

Giemsa staining Bar=10um

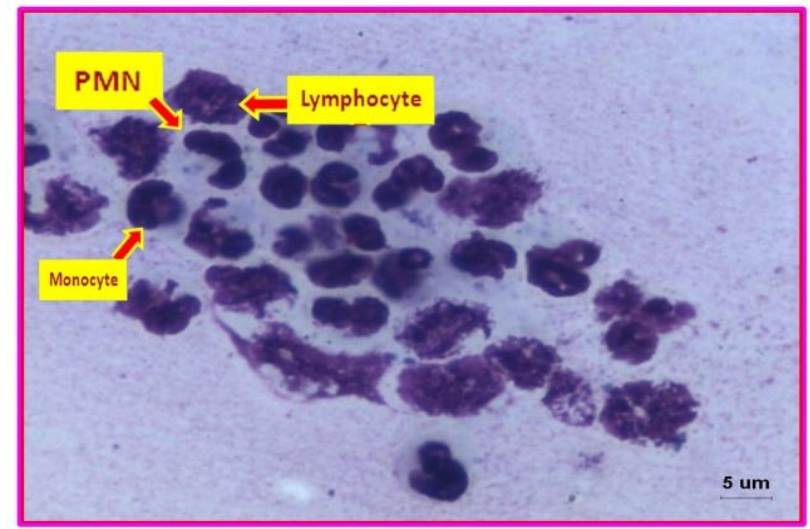

Giemsa staining Bar=5um

Fig. 2 
In the present investigation, uterine lavage technique was adopted for the cytological studies of the uterus. Various techniques such as direct swab (Chapwanya et al., 2010) cytobrush (Barlund et al., 2008) and lavage techniques (Kasimanickam et al., 2005) were used for this purpose. In this experiment, in all the treatment and control groups the number of PMN cells were higher on day 2 postpartum than on day 10 postpartum. The cellular defence in uterus against bacterial contamination was provided by uterine leucocytes (Vandeplassche and Bouters, 1983), believed to be migrated from the peripheral circulation. PMNs were the predominant inflammatory cell types found in the uterine fluid (Gilbert et al., 2005). In this investigation, the fully dilated cervix at the time of parturition might have caused entry of bacteria into the uterus and this might have increased the PMNs on day 2 postpartum.

Interestingly in this study, the mean number of PMN cells showed drastic decreasing trend from day 2 postpartum to day 30 postpartum in all the treatment groups with the maximum decrease in group I and III than group II and control cows. PMN influx into the uterus got reduced after the administration of these drugs as suggested by Uthai et al., (2013). In these 3 treatment groups, a reduction in mean number of PMN and increased in mean lymphocytes were observed in this study. An increase segmented neutrophils (or PMN) in the endometrium was associated with poor reproductive performance whereas the presence of lymphocytes in the endometrium was associated with good fertility (Bonnett et al., 1993). These observations might explain the improved conception rate in treatment groups of this study. Among the 3 treatment groups, the mean numbers of lymphocytes were found to be higher in group I followed by group III and II and this pattern concurred with the conception rate of each group in this study.

\section{References}

Azawi, O.I. 2008. Postpartum uterine infection in cattle. Anim. Reprod. Sci., 105: 187-208.

Barlund, C.S., T.D. Carruthers, C.L. Waldner and C.W. Palmer, 2008. A comparison of diagnostic techniques for postpartum endometritis in dairy cattle. Theriogenology, 69: 714-23.

Bonnett, B.N., S.W. Martin and A.H. Mekk, 1993.Associations of clinical findings, bacteriological and histological results of endometrial biopsy with reproductive performance of postpartum dairy cow. Prev. Vet. Med., 15: 205-220.

Chapwanya, A., K.G. Meade, F. Narciandi, P. Stanley, J.F. Mee, M.L. Doherty, J.J. Callanan and C. O'Farrelly, 2010. Endometrial biopsy: a valuable clinical and research tool in bovine reproduction. Theriogenology, 73: 988994.

Dijkhuizen, A.A. and J.R. Stelwagen, 1985. Economic aspects of reproductive failure in dairy cattle. Financial loss at the farm level. Prev. Vet. Med., 3: 251263.

Dolatkhah, B., A.H. Mahdavi, H.R. Rahmani, M.A. Edriss and M. Khorvash, 2013. Cytologic and histologic characteristics of endometritis in postpartum dairy cows. Annals Bio. Res., 4:70-76.

Ferguson, J.D. and D.T.Galligan, 2000. Assessment of reproductive efficiency in dairy herds. Com. Cont. Edu. Prac. Vet., 22: $150-158$.

Frazer, G.S. 2005. A rational basis for therapy in the sick postpartum cow.Vet. Clin.north American. food anim. pract., 21: 523-68.

Gilbert, R.O., S.T. Shin, C.L. Guard, H.N. Erb and M. Frajblat, 2005. Prevalence of endometritis and its effects on reproductive performance of dairy cows. Theriogenology, 64: 1879-1888. 
Kasimanickam, R., T.F. Duffield, R.A. Foster, C.J. Gartley, K.E. Leslie, J.S. Waltonand W.H. Johnson, 2005. A comparison of the cytobrush and uterine lavage techniques to evaluate endometrial cytology in clinically normal postpartum dairy cows. Canadian Vet. J., 46: 255-259.

Mateus, L., L.L. Costa, F. Bernardo and J.R. Silva, 2002. Influence of puerperal uterine infection on uterine involution and postpartum ovarian activity in dairy cows. Reprod. Dom. Anim., 37: 31-35.

Nakao, T., M. Moriyoshi and K. Kawata, 1992. The effect of postpartum ovarian dysfunction and endometritis on subsequent reproductive performance in high and medium producing dairy herds. Theriogenology, 32: 2.

Nebel, R. L. 1999. Optimizing fertility in the dairy herd. Proceedings Annual Conference Society. Theriogenology, 20: 443-452.

Patel, P.M., A.J. Dhami, T.V. Hinsu, V.P. Ramani, N.P. Sarvaiya and F.S. Kavani, 2006.Comparative evaluation of blood biochemical and progesterone profile of fertile and infertile estrous cycles in postpartum Holstein Friesian cows. Indian J. Anim. Sci., 76: 191-195.

Peter, A.T., P.L.A.M. Vos and D.J. Ambrose, 2009.Postpartum anestrus in dairy cattle. Theriogenology, 71: 1333-1342.

Promod, K., S. Mahrnood and R. Singh, 2002. Cytological changes during certain reproductive condition in in vitro uterine flushings in buffaloes (Bubalus bubalis). Indian J. Anim. Reprod., 23: 123-125.

Schalm, O.W., N.C. Jain and E.J. Corrol, 1975.Veterinary haematology. $3^{\text {rd }}$ edition, Lea and Febiger, Philadelphia, USA.

Singh, J., S.S. Sidhu, G.S. Dhaliwal, G.R. Pangaonkar, A.S. Nanda and A.S. Grewal, 2000. Effectiveness of lipopolysaccharide as an intrauterine crossbred cows. Anim. Reprod. Sci., 59: 159-66.

Tiwari, R.P., S. Jogi and S.K. Sahu, 2004. Effect of prostaglandin administration after calving in buffaloes on postpartum reproductive performance. Buffalo Bulle, 23: 53-57.

Uthai, T.S., Q. Chen, S.E. Kirton, M.A. Fenwick, Z. Cheng, J. Patton, A.A. Fouladi-Nashta and D.C. Wathes, 2013. Influence of energy balance on the antimicrobial peptides S100A8 and S100A9 in the endometrium of the postpartum dairy cow. Reprod., 145: 527539.

Vandeplassche, M. and R. Bouters, 1983. Phagocytosis in the blood and uterine exudates of mares cows and sows. World Assn. Vet. Lab. Dia. Ames, 1: 8389.

Zain, A.E., T. Nakao, M.A. Raouf, M. Moriyoshi, K. Kawata and Y. Moritsu, 1995.Factors in the resumption of ovarian activity and uterine involution in postpartum dairy cows. Anim. Reprod. Sci., 38: 203-214.

\section{How to cite this article:}

Alagar, S., M. Selvaraju and Ezakial Napolean, R. 2017. Cytological Indices of Postpartum Normally Calved Dairy Cows. Int.J.Curr.Microbiol.App.Sci. 6(11): 2617-2622. doi: https://doi.org/10.20546/ijcmas.2017.611.307 